\title{
SASTRA CYBER DI INDONESIA
}

\section{Laily Fitriani}

Dosen Jurusan Bahasa dan Sastra Arab,

Fakultas Humaniora dan Budaya, Universitas Islam Negeri (UIN) Malang.

Jalan Gajayana No. 50 Telepon (0341) 570872, Faksimile (0341) 570872 Malang 65144.

E-Mail: <fitrieahmad@yahoo.com>

\begin{abstract}
The digital era started when the internet technology spread to the developing countries including Indonesia. The flourish of cyber literature leads to the debate on the quality of the work of literature. Above all, the existence of literature sites (cyber literature) becomes an important alternative for writers and literary activist in Indonesia.
\end{abstract}

\section{Keywords}

Literatur Cyber, Literature Printing, Digital

\section{Pendahuluan}

Salah satu ciri karya sastra yang sangat penting adalah fungsi komunikasi. Memang benar karya sastra dihasilkan melalui imajinasi dan kreativitas sebagai hasil kontemplasi secara individual, tetapi karya sastra juga ditujukan untuk menyampaikan suatu pesan kepada orang lain sebagai komunikasi. Secara garis besar komunikasi dilakukan melalui: a) interaksi sosial, b) aktivitas bahasa (lisan dan tulisan), dan c) mekanisme teknologi (Ratna, 2007:297-298).

Dunia semakin kencang berputar. Hasil-hasil kebudayaan manusia tidak saja tertumpu pada keyakinan tentang bagaimana bisa bertahan hidup, tetapi sudah mencapai ke taraf pengembangan yang 
sering tidak diduga-duga. Mungkin, sekitar 40 tahun yang lalu, tidak pernah terpikir oleh manusia ketika itu tentang adanya komputer apalagi dunia maya alias internet.

Dalam tulisan Rulli Nasrullah berjudul "Cyber Culture" yang dimuat di Padang Ekspres pada 6 Mei 2007 yang lalu. Menurut Rulli keberadaan internet mampu membentuk sebuah kultur baru dimana batas-batas geografis, demografis, etnisitas, ras, dan agama, hingga budaya menjadi tersamarkan. Kultur baru tersebut merupakan perwujudan dari keinginan para netter untuk hidup secara demokratis. Tanpa ada intervensi, sikap egois, ingin menyamakan kehidupan dunia maya seperti dunia nyata (http://www.mywritingblogs.com).

Percaya atau tidak percaya apa yang kita baca hari ini dari buku, koran atau apapun yang berbentuk media cetak lainnya, berangsurangsur akan digantikan oleh media elektronik. Begitu juga dengan sastra yang semula melalui teks tercetak, akan berubah wujud kedalam kemasan digital.

Oleh karena itu, dunia tulis menulis dalam hal ini ruang lingkup sastra pun tak luput dan telah menjadi 'korban' pula dari geliat dunia maya. Koran atau media cetak yang selama ini menjadi tumpuan penulis, telah tersaingi oleh dunia maya.

\section{Definisi Sastra Cyber}

Istilah cybersastra, dapat dirunut dari asal katanya. Cyber, dalam bahasa Inggris tidaklah berdiri sendiri, melainkan terjalin dengan kata lain seperti cyberspace, cybernate, dan cybernetics. Cyberspace berarti ruang (berkomputer) yang saling terjalin membentuk budaya di kalangan mereka. Cybernate, berarti pengendalian proses menggunakan komputer. Cybernetics berarti mengacu pada sistem kendali otomatis, baik dalam sistem komputer (elektronik) maupun jaringan syaraf. Dari pengertian ini dapat dikemukakan bahwa cybersastra adalah aktivitas sastra yang memanfaatkan media komputer atau internet (Enraswara, 2006:182). 


\section{Keberadaan Sastra Cyber Dibanding Sastra Cetak}

Munculnya istilah Sastra Cyber sendiri bermula dengan hadirnya komunitas-komunitas (milis) di dunia maya. Milis penyair adalah satu milis yang merupakan tonggak lahirnya Sastra Cyber Indonesia. Di dalam perkembangannya, sastra cyber melahirkan tiga bentuk wajah yaitu Sastra Milis, Sastra Portal, dan Sastra Blog (http://www.mywritingblogs.com).

Istilah Sastra Cyber atau Cybersastra mulai populer memang baru belakangan ini. Sejak tahun 2001 baru merebak istilah demikian. Yakni, pada saat budaya internet mulai berkecamuk di negeri kita. Melalui internet tersebut muncul cybersastra. Secara tidak langsung munculnya cybersastra telah menabuh 'gong besar' fenomena dunia sastra, khususnya yang berkembang di Indonesia. Cybersastra mampu menembus, menjebol dinding-dinding sastra yang selama ini cenderung 'inklusif' bagi para penulis pemula.

Selama ini penulis-penulis pemula merasakan ada pertanyaan besar yang muncul di benak mereka ketika karya-karya yang mereka buat dan kirim tidak terekspose dunia sastra cetak (koran atau majalah), mengapa pihak sastra cetak hanya mengandalkan dan memuat karyakarya besar sastrawan ternama saja? mengapa mereka tidak? yang notabene-nya juga sastrawan (baca: penulis pemula)? Pertanyaanpertanyaan beragam juga banyak mengitari kepala mereka, sehingga ketika seorang penulis pemula yang ingin memproklamirkan dirinya sebagai sastrawan baru harus berputar otak mencari jalan bagaimana keberadaannya segera diakui publik. Hal ini tidak lepas dari 'ruwetnya' 'birokrasi' sastra cetak di tanah air, sehingga muncul pernyataan yang mengatakan jika tulisan atau karya-karya seorang penulis pemula belum pernah dimuat di Kompas (salah satu media cetak di Indonesia), maka jangan harap diakui oleh publik. Ini sebuah tanda tanya besar, ada apa dengan dunia sastra kita?

Sastra cyber atau cybersastra muncul menjawab kegelisahan para penulis atau sastrawan pemula. Sastra cyber atau Cybersastra sebagai wahana penyalur segala bentuk inspirasi bagi penulis pemula yang 
menjadi tonggak baru kehadiran dunia sastra yang sifatnya 'bebas' tak mengenal ruang, waktu, bahasa, dan mendobrak sekat-sekat negara, karena dengan beberapa detik tulisan yang dimuat akan terekspose ke seluruh belahan negara. Hal ini bisa saja menandai era baru 'matinya sastra cetak'. Walaupun harus diakui bahwa, koran dan media cetak telah punya andil dalam membesarkan nama-nama sastrawan. Namun, menganggap koran atau media cetak menjadi satu-satunya sumber untuk membuat seseorang menjadi sastrawan juga sebuah opini yang menyesatkan pada era keterbukaan dan era digital ini (http://www.sawali.wordpress.com).

Dalam buku "Sastra Pembebasan Antologi Puisi-Cerpen-Esai" yang diterbitkan Yayasan Damar Warga tahun 2004, Theora Aghata dalam esainya "Sastra Cyber: Beberapa Catatan" mengungkapkan bahwa keberadaan sastra cyber telah menjadi wahana dan wacana sangat penting, justru karena fleksibilitas dan kemampuannya untuk menjadi sebuah barometer baru bagi kemajuan sastra kita (Indonesia) di masa depan.

Peranan strategis sastra cyber menurut Theora Aghata merupakan wahana berkreasi yang mampu mengupdate karya secara singkat sehingga menunjang produktivitas dan mendorong perkembangan sastra selain juga mengembangkan wacana kritis dan asah kemampuan maupun pemikiran. Meskipun sifat media internet yang serba instant dan bisa saja memunculkan budaya instant, namun semua tergantung kepada keadaan para penulis cyber. Jika mereka mampu bersikap profesional yaitu mempertahankan produktivitas karya, maka bisa saja sastra cyber menjadi corak yang memunculkan angkatan baru dalam kancah perkembangan sastra Indonesia (http://www.mywritingblogs.com).

\section{Alasan Penulis Memilih Sastra Cyber}

Diantara beberapa alasan Penulis atau sastrawan terjun ke cybersastra adalah: 
Pertama; Penulis ingin mencari model baru kreativitas dan ingin meninggalkan tradisi lama yang menjenuhkan. Mereka menganggap cybersastra adalah ladang yang menjanjikan. Cybersastra akan lebih mewakili keinginan dan daya juang kreativitas, karena masih terbatas yang berminat kearah situ. Daya saing merekapun masih terbatas, sehingga karya seperti apa saja akan semakin diakui eksistensinya.

Kedua; Mereka ada yang ingin segera mencari popularitas. Lewat cybersastra yang terbatas komunitasnya, sebaliknya diri pengarang dapat mudah tersebar ke seluruh penjuru dunia, nama mereka tak perlu harus melewati 'wisuda khusus'. Nama penulis akan terangkat dan segera terkenal ke seluruh jaringan cyber.

Ketiga; Ada diantara mereka yang sekedar iseng bermain internet, dan ingin meloloskan diri dari penjara sastra koran. Mereka beranggapan bahwa sastra koran dan buku terlalu hegemonik. Masingmasing penerbit memiliki strategi, ada model "KKN" (Korupsi, Kolusi, Nepotisme) di dalamnya, sehingga tak semua karya penulis pemula tercakup (Enraswara, 2006:183).

\section{Kualitas Karya Sastra Cyber Dibanding Sastra Cetak}

Pada dasarnya orientasi terhadap karya sastra itu ada empat macam seperti digambarkan oleh Abrams (1976:6) dalam Pradopo. Pertama, karya sastra itu merupakan tiruan alam atau penggambaran alam; kedua, karya sastra itu merupakan alat atau sarana untuk mencapai tujuan tertentu pada pembacanya; ketiga, karya sastra itu merupakan pancaran perasaan, pikiran, ataupun pengalaman sastrawan; dan keempat, karya sastra itu merupakan sesuatu yang otonom, mandiri, lepas dari alam sekelilingnya, pembaca, maupun pengarangnya (Pradopo, 2003:206-207).

Menelaah sebuah karya sastra dan sampai pada kesimpulan apakah karya sastra tersebut berkualitas atau tidak, bukanlah persoalan mudah karena penilaian yang dilakukan tidak mungkin hanya didasarkan pada salah satu elemennya, melainkan harus dilihat secara keseluruhan. Oleh sebab itu, karya sastra yang hanya bagus dalam salah 
satu aspeknya, belum dapat dikatakan sebagai sastra yang berkualitas atau sastra yang baik. Begitu pula karya sastra yang tidak mudah dipahami oleh setiap orang tidak bisa langsung disebut sebagai sastra yang kurang berkualitas. Yang paling mendasar adalah apakah karya sastra tersebut sudah memenuhi kriteria kualitas sastra yang ada, seperti kriteria estetik dan kriteria struktur (struktur dalam dan luar) (Fananie, 2000:73-74).

Dengan hadirnya sastra cyber atau cybersastra muncul pula perdebatan soal mutu dan kualitas sastra cyber. Banyak pemerhati sastra yang menilai teks-teks sastra yang tergolong 'sampah' mudah terpublikasikan. Hal yang (hampir) mustahil terjadi dalam sastra koran. Untuk bisa meloloskan teks sastranya ke sebuah media cetak, minimal harus lolos dari persyaratan ketat yang telah ditetapkan oleh redaktur (http://sawali.wordpress.com).

Sebenarnya dikotomi antara sastra koran dan sastra cyber itu hanya berbeda pada penggunaan medianya saja. Sastra sangat erat kaitannya dengan dunia imajinasi. Siapapun itu, baik penulis/sastrawan terkenal ataupun penulis/sastrawan pemula bebas dan berhak mengekspresikan imajinasi, menafsirkan nilai-nilai estetika dan bebas menyampaikan pesan-pesan moral yang dibawanya. Persoalannya, sastra koran mengenal batasan-batasan yang dikendalikan oleh otoritas sang redaktur dan selera pasar, sedang sastra cyber cenderung hampir tidak mengenal batas-batas itu.

Ketika setiap orang memiliki blog gratisan, maka ia akan lebih mudah dalam mengekpresikan serta mempublikasikan karya sastra serta saling berkomentar seputar dunia sastra dan sebagainya dengan penulis/sastrawan lain tanpa mengeluarkan biaya dibandingkan dengan sastra koran yang hanya terbatas segmen pembacanya dan rubrik sastra hanya muncul sekali dalam seminggu dengan alasan sebagai pelengkap dunia hiburan semata.

Maraknya blogger yang memuat karya sastra dan juga kemudahan memuat suatu karya di situs internet, di lain pihak ditanggapi secara sinis oleh sebagian orang. Bagi mereka, karya sastra 
semacam ini adalah 'sampah' karena tak memenuhi standar baku karya sastra. Namun penilaian ini kurang bisa dipertanggungjawabkan karena masih hanya berdasar survei secara kuantitatif, yang kemudian dipakai untuk memberikan penilaian secara umum. Padahal, jika kita mencermati secara seksama, dari sekian banyak blogger itu, beberapa karyanya tak kalah menarik jika dibandingkan dengan yang dimuat di media cetak (http://www.hayamwuruk-online.blogspot.com).

Ini artinya media juga mempunyai peran penting dalam keberadaan menghidupkan karya sastra. Sebuah produk budaya, apabila tak dapat di konsumsi oleh khalayak atau publik maka karya sastra itu akan menguap tanpa makna. Hal ini mungkin dapat disebut sebagai sebuah bentuk pencarian jati diri penulis pemula untuk publik dalam hal menikmati karya-karya yang 'dihidangkan', terserah publik yang akan menilai sejauh mana kualitas dan mutu sebuah karya sastra tersebut.

Berbicara tentang mutu dan kualitas karya-karya sastra cyber, jika kita cermati beberapa karya-karya penulis pemula baik itu cerpen, novel, puisi dan sebagainya kita dapat melihat bentuk-bentuk diksi yang digunakan, isi, ataupun tema yang beragam disuguhkan sangat menarik dan tidak jauh berbeda dengan mereka-mereka yang sudah terkenal. Kalau selama ini label 'sampah' membanjiri karya-karya cybersastra, itu hanya pandangan negatif mereka yang tidak setuju dengan adanya sastra cyber. Sebenarnya apa kategori sastra berlabel 'sampah' itu? Semuanya kita kembalikan pada publik yang akan mencerna dan mengkritisi karya-karya tersebut, jikalau karya itu tergolong 'sampah' maka lambat laun karya-karya itu akan terkikis, hilang di telan waktu, dikalahkan karya-karya yang memang patut diperhitungkan di kancah pergulatan sastra Indonesia.

\section{Penutup}

Cybersastra ternyata mampu membebaskan imajinasi penulis untuk menciptakan karya-karya yang layak diperhitungkan. Dunia baru ini dianggap menjadi tonggak baru dunia sastra Indonesia yang selama 
ini terkesan 'inklusif' untuk lebih membumi di kalangan seluruh lapisan penulis, khususnya penulis pemula. Diakui atau tidak cybersastra mampu menjawab kegelisahan jiwa penulis pemula untuk mendapatkan 'ruang' dalam pergulatan kancah dunia sastra Indonesia. $\square$

\section{DAFTAR PUSTAKA}

Enraswara, Suwardi. 2006. Metodologi Penelitian Sastra, Epistemologi, Model, Teori dan Aplikasi. Yogyakarta: Pustaka Widyatama.

Fananie, Zainuddin. 2000. Telaah Sastra. Surakarta: Muhammadiyah University Press.

Pradopo, Rachmat Djoko. 2003. Beberapa Teori Sastra, Metode Kritik, dan Penerapannya. Yogyakarta: Pustaka Pelajar. 
Ratna, Nyoman Kutha. 2007. Teori, Metode, dan Teknik Penelitian Sastra. Yogyakarta: Pustaka Pelajar.

(http://hayamwuruk-online.blogspot.com)

(http://mywritingblogs.com)

(http://sawali.wordpress.com) 